\title{
ALAT PERMAINAN EDUKATIF LEGO MENINGKATKAN PERKEMBANGAN MOTORIK HALUS ANAK USIA PRASEKOLAH
}

\author{
Tunggul Sri Agus Setyaningsih ${ }^{1}$, Hesti Wahyuni ${ }^{2}$ \\ ${ }^{1,2)}$ Akademi Keperawatan RS Dustira Cimahi \\ Email : tunggulsas99@gmail.com
}

\begin{abstract}
ABSTRAK
Proses tumbuh kembang kemampuan motorik halus dapat terlihat melalui berbagai gerakan dan permainan yang dilakukan anak. Stimulasi yang sangat tepat dan menyenangkan bagi anak untuk meningkatkan dan memicu kemampuan motorik halus dapat dilakukan menggunakan permainan edukatif. Tujuan penelitian adalah menganalisis pengaruh penggunaan alat permainan edukatif terhadap perkembangan motorik halus pada anak usia prasekolah. Penelitian ini menggunakan metode kuantitatif, desain quasi eksperimental one group pre test-post test. Teknik yang digunakan purposive sampling. Instrumen yang digunakan yaitu Alat Permainan Edukatif (APE) Lego dan Kuesioner Pra Skrining Perkembangan (KPSP). Hasil penelitian dianalisis dengan menggunakan uji Wilcoxon nilai $\mathrm{p}=0,000$ (nilai signifikan $\mathrm{p}$-value $<0,05$ ). Hasil tersebut menunjukkan ada pengaruh alat permainan edukatif terhadap perkembangan motorik halus anak usia prasekolah di TK At-Taqwa Cimahi, selanjutnya disarankan untuk dapat memberikan permainan edukatif untuk menstimulasi aspek perkembangan anak.
\end{abstract}

Kata Kunci: Alat Permainan Edukatif, Anak Usia Prasekolah, Perkembangan Motorik Halus, Lego

\begin{abstract}
The process of growth and development of fine motor skills can be seen through various movements and games made by children. Very precise stimulation and fun for children to improve and trigger fine motor skills can be done using educational games. The purpose of this study was to analyze the effect of the use of educational toys on fine motor development in preschool children. This research was a quantitative method with a quasi experimental one group pre-post-test design. The technique used is purpossive sampling. The instruments used are Lego Educational Game Tools (APE) and Pre Development Screening Questionnaire $(K P S P)$. The results of the study were analyzed using the Wilcoxon test $p$ value $=0,000$ (significant p-value <0.05). These results indicate there is an influence of educational play tools on the fine motor development of preschool age children in At-Taqwa Cimahi Kindergarten, furthermore it is suggested to be able to provide educational games to stimulate aspects of child development.
\end{abstract}

Keywords: Educational Game Tools, Preschool Children, Fine Motor Development, Lego 


\section{LATAR BELAKANG}

Anak usia prasekolah yang merupakan fase usia emas (golden age) yang memiliki peranan penting untuk mengembangkan berbagai potensi. Tahun-tahun pertama kehidupan anak merupakan masa-masa penting, baik secara fisik maupun mental, materi-materi pengajarannya harus dicocokkan dengan kebutuhannya untuk belajar melalui gerakan, karena gerakan akan mengawali kerja kognitif (Fuadiyah, 2013). Perkembangan motorik halus merupakan aspek yang berhubungan dengan kemampuan anak melakukan gerakan yang melibatkan bagian-bagian tubuh tertentu dan dilakukan oleh otot-otot kecil, tetapi memerlukan koordinasi yang cermat (Kemenkes, 2012).

Kurangnya stimulasi pada anak dapat menyebabkan penyimpangan tumbuh kembang anak bahkan gangguan yang menetap (Soetjiningsih, 2013). Dilansir dari data UNICEF tahun 2011 menjelaskan bahwa 27,5\% dari 3 juta anak menggunakan pengembangan motorik halusnya. Data UNICEF pada tahun 2012 menyebutkan angka kejadian gangguan motorik halus pada anak pra-sekolah di Amerika Serikat berkisar 12$16 \%$, Thailand 24\%, Argentina 22\%, dan di Indonesia antara 13\%-18\%. Melihat angka epidemiologi tersebut, maka diperlukan adanya deteksi dini pada anak dengan gangguan perkembangan untuk mencegah terjadinya keterlambatan penanganan (Livana et al., 2018). Apabila gangguan perkembangan tidak ditangani dengan tepat, maka dapat berlanjut hingga remaja atau dewasa (Susanto, 2016). Anak usia prasekolah mengalami gangguan perkembangan sebesar 62,02\% (Ikram, 2018).

Untuk membantu anak mencapai tingkat perkembangan yang optimal atau sesuai dengan yang diharapkan, salah satunya dengan memberikan stimulasi terarah sebagai penguat (reinforcement), rutin sedini mungkin dan terus-menerus pada setiap kesempatan dan lebih efektif dengan memperhatikan kebutuhan-kebutuhan anak sesuai dengan tahap perkembangannya pada kemampuan dasar yang meliputi gerak kasar, gerak halus, bicara, dan bahasa serta sosialisasi dan kemandirian (Soetjiningsih, 2013). Alat permainan edukuatif dapat meningkatkan motorik halus anak, terbukti ada peningkatan motorik halus anak (Livana et al., 2018). Proses tumbuh kembang kemampuan motorik halus dapat terlihat melalui berbagai gerakan dan permainan yang dapat dilakukan (Winarti, 2016).

Berdasarkan data WHO, jumlah anak yang diberikan stimulasi permainan edukatif oleh orang tuanya berjumlah 23,50\%, sedangkan pada tahun 2010 mencapai 27,30\% dan pada tahun 2011 mengalami peningkatan yang signifikan hingga 34,85\%. Indonesia pada tahun 2010 jumlah anak yang diberikan permainan edukatif pada tahun 2009 mencapai 23.000 jiwa, pada tahun 2010 mencapai 24.120 jiwa dan pada tahun2011 mencapai 25.100 jiwa. Berdasarkan laporan dari Departemen Kesehatan Republik Indonesia tahun 2010 cakupan pelayanan kesehatan balita dalam deteksi tumbuh kembang balita yang mengalami gangguan tumbuh kembang anak di Indonesia sebanyak 45,7\% (Riska \& Satria, 2016).

Alat permainan edukatif yang baik akan lebih menarik untuk anak dari pada alat permainan yang tidak didesain dengan baik, sebab anak usia prasekolah biasanya menyukai alat permainan dengan contoh yang sederhana dan tidak rumit serta berwarna terang. APE untuk anak selalu dirancang dengan pemikiran yang mendalam disesuaikan dengan rentang usia anak untuk mengembangkan aspek-aspek perkembangan anak (motorik halus dan kasar), emosi, sosial, bahasa, kognitif, dan moral (Mahardikha \& Yuniarni, n.d., 2013). Permainan lego termasuk permainan yang meningkatkan perkembangan anak, dan terlebih dalam perkembangan motorik halusnya. Menyusun 
lego terlihat sederhana, hanya menempel atau menggabungkan sehingga menjadi satu bentuk baru yang menarik (Christiana \& Mahmudah, 2015). Penelitian ini bertujuan untuk mengetahui pengaruh penggunaan alat permainan edukatif terhadap perkembangan motorik halus anak usia prasekolah.

\section{METODE PENELITIAN}

Penelitian ini menggunakan metode kuantitatif, quasi eksperimental dengan one group pre test -post test design. Pengambilan data menggunakan teknik purpossive sampling. Penelitian ini mengukur perkembangan motorik halus sebelum dan sesudah diberikan alat permainan edukatif lego. Tahapan yang dilakukan dalam penelitian ini yaitu memilih responden yang sesuai dengan kriteria dengan cara memeriksa satu persatu untuk mendapatkan anak sesuai dengan kriteria inklusi. Peneliti memperkenalkan diri, menjelaskan maksud dan tujuan penelitian kepada orang tua, memberikan informasi terkait dengan penelitian, meminta kesediaan orangtua agar anak diperkenankan menjadi responden dalam penelitian, jika keluarga bersedia keluarga diminta menandatangani lembar persetujuan responden (informed consent). Menyiapkan prosedur pemberian permainan edukatif lego kepada responden. Cara bermain lego yaitu dengan mencampur kepingan-kepingan lego menjadi satu rangkaian, kemudian menatanya kembali menjadi bentuk tertentu yang sudah ditentukan. Anak menyusun lego sesuai dengan susunan yang benar. Penelitian ini dilakukan pada 17 anak prasekolah (usia 54 dan 60 bulan) dengan kriteria meragukan pada aspek perkembangan motorik halus di TK At-Taqwa Cimahi. Peneliti memberikan alat permainan edukatif berupa lego selama 15 menit selama 2 minggu. Penilaian perkembangan dengan menggunakan Kuesioner Pra Skrining Perkembangan (KPSP) berdasarkan buku pedoman pelaksanaan stimulasi, deteksi dan intervensi dini tumbuh kembang anak (SDIDTK) (Kemenkes, 2012), jika dideteksi diperoleh keterlambatan (meragukan) pada perkembangan motorik halus anak maka diberikan intervensi stimulasi alat permainan edukatif selama 2 minggu. Apabila dideteksi perkembangan anak hasilnya sesuai berarti anak berhasil menyesuaikan diri dengan tahap perkembangan normal. Penelitian dianalisis dengan menggunakan uji statistik Wilcoxon.

\section{HASIL DAN PEMBAHASAN}

Penelitian ini dilakukan pada anak usia prasekolah. Masa usia ini merupakan dasar perkembangan untuk tahap tumbuh kembang selanjutknya sehingga harus dioptimalkan. Diperlukan stimulasi yang tepat bagi anak untuk mencapainya, salah satunya melalui penggunaan alat permainan edukatif lego. Penilaian perkembangan anak dilakukan dengan menggunakan KPSP sebelum dan sesudah diberikan alat permainan edukatif lego. Semua anak diberikan alat permainan edukatif berupa lego selama 15 menit dalam 2 minggu.

Hasil penelitian menunjukkan bahwa rerata perkembangan anak sesudah diberikan alat permainan edukatif lego yaitu 3.35 dengan standar deviasi 0.702. Ini menunjukkan bahwa rata-rata perkembangan mengalami peningkatan. Perkembangan motorik halus anak sebelum diberikan alat permainan edukatif lego nilai minimum 1 (Meragukan) dan maksimum 2 (Meragukan), sedangkan perkembangan motorik halus anak sesudah di berikan alat permainan edukatif lego yaitu nilai minimum 2 (Meragukan) dan nilai maksimum 4 (Sesuai). Berdasarkan hasil analisis uji statistik dengan menggunakan uji Wilcoxon, didapatkan $\mathrm{P}$ value $<0,05(=0.000)$, artinya ada pengaruh alat permainan edukatif terhadap perkembangan motorik halus anak usia prasekolah. Terdapat 2 anak 
(11.76\%) masih meragukan dan 15 anak (88.23\%) sesuai pada aspek perkembangan motorik halus.

Tabel 1

Karakteristik Responden Penelitian

\begin{tabular}{llcc}
\hline Karakteristik & Kategori & Frekuensi & Persentase \\
\hline \multirow{2}{*}{ Usia } & 54 bulan & 10 & 58.8 \\
\cline { 2 - 4 } & 60 bulan & 7 & 41.2 \\
\hline \multirow{2}{*}{ Jenis Kelamin } & Laki-laki & 11 & 64.7 \\
\cline { 2 - 4 } & Perempuan & 6 & 35.3 \\
\hline
\end{tabular}

Tabel 2

Pengaruh Alat Permainan Edukatif Lego terhadap Perkembangan Motorik Halus Anak Usia Prasekolah

\begin{tabular}{lccc}
\hline \multicolumn{1}{c}{ Indikator } & Sebelum Intervensi & $\begin{array}{c}\text { Setelah } \\
\text { Intervensi }\end{array}$ & $p$ \\
\hline $\begin{array}{l}\text { Rerata Perkembangan } \\
\begin{array}{l}\text { Motorik Halus } \\
\text { (SD) }\end{array}\end{array}$ & 1.59 & 3.35 & 0.000 \\
\hline
\end{tabular}

Penelitian ini dilakukan pada anak usia prasekolah. Anak usia prasekolah adalah anak usia 3-6 tahun yang belum menempuh sekolah dasar (Kemenkes, 2012). Usia prasekolah yang merupakan usia emas (golden age). Pada usia ini anak memiliki peranan penting untuk mengembangkan berbagai potensi. Usia 3-6 tahun, seorang anak tumbuh dengan cepat, namun tidak secepat masa sebelumnya, mulai kehilangan bentuk kebayiannya dan mulai mengambil bentuk masa kanak-kanak yang ramping dan atletis. Seiring dengan mengerasnya otot perut, kegendutan khas bayi mulai menghilang. Tubuh, tangan dan kaki tumbuh semakin panjang. Perkembangan otot dan tulang membuat anak semakin kuat. Anak prasekolah membuat kemajuan yang besar dalam keterampilan motorik halus (fine motor skill) (Papalia et al., 2010). Anak usia usia prasekolah merupakan tahapan usia yang sangat membutuhkan stimulasi dini untuk perkembangan motorik halusnya (Wahyuni, 2018). Perkembangan anak pada usia 4-6 tahun sangat peka terhadap stimulus dan pengalaman serta mempunyai kemampuan plastisitas yang tinggi, anak usia 3-6 tahun jika diberikan stimulasi motorik halus mampu menulis, menggambar, menyusun balok dan memasukkan kelereng sesuai dengan tahap perkembangannya (Livana et al., 2018). Jenis kelamin anak menentukan perkembangan motorik halus anak usia prasekolah (Wahyuni, 2018). Responden dalam penelitian ini terdapat laki-laki sebanyak 11 (64.7\%) dan perempuan 6 (35.3\%). Anak perempuan akan mudah diberikan stimulasi dibandingkan anak laki-laki karena anak perempuan lebih mudah diatur dari pada anak laki-laki (Livana et al., 2018).

Gerakan motorik halus terutama melibatkan otot tangan dan jari biasanya membutuhkan kecermatan tinggi, ketekunan dan koordinasi antara mata dan otot kecil (Hildayani \& Psi, 2014). Diperlukan stimulasi untuk mendukung perkembangan motorik halus anak. Stimulasi yang tepat bagi anak dapat dilakukan melalui permainan karena dengan bermain anak akan belajar sehingga aspek perkembangan dapat ditumbuhkan lebih sehat sekaligus cerdas secara optimal (Wong, 2009). Masa prasekolah sebagai masa bermain, hampir seluruh kegiatan pada usia prasekolah perlu melibatkan unsur bermain (Setyaningsih \& Wahyuni, 2018). Bermain pada usia prasekolah telah terbukti mampu merangsang perkembangan mental dan kecerdasan daya pikir sehingga dapat mendayagunakan aspek emosional, sosial, serta fisiknya (Adriana, 2013). 
Upaya yang dapat dilakukan untuk meningkatkan kemampuan motorik halus anak yaitu dengan memberikan stimulasi dari luar seperti memberikan permainan edukatif yang dapat memicu peningkatan perkembangan motorik halus dan kreatifitas anak seperti memberikan permainan lego konstruktif, sehingga diharapkan anak dapat membuat sesuatu hal yang baru yang memberikan nilai seni sesuai dengan ide yang dimilikinya (Winarti, 2016).

Alat Permainan Edukatif (APE) merupakan alat permainan untuk anak usia dini yang dapat mengoptimalkan perkembangan anak, yang dapat disesuaikan penggunaannya menurut usianya dan tingkat perkembangan anak serta berguna untuk pengembangan aspek fisik anak, bahasa dengan melatih berbicara dan menggunakan kalimat yang benar, kognitif dengan pengenalan suara, ukuran, bentuk, warna, dan sosial anak khususnya dalam hubungannya dengan interaksi antara ibu dan anak, keluarga dan masyarakat. Alat permainan edukatif harus memenuhi syarat aman (tidak boleh ada bagian-bagian yang tajam, mudah pecah dan mudah rusak), ukuran dan berat harus sesuai dengan anak, rancangannya harus jelas mempunyai ukuran-ukuran, susunan dan warna tertentu, serta jelas maksud dan tujuannya, dan harus mempunyai fungsi untuk mengembangkan berbagai aspek perkembangan anak (Soetjiningsih, 2013).

Anak usia dini dapat dilatih dan distimulus melalui kegiatan bermain. Mulai dari kegiatan bermain sederhana sampai yang amat rumit seperti lego. Lego merupakan alat permainan edukatif yang terbuat dari plastik, berupa potongan-potongan persegi, tabung atau kerucut yang masing-masing dapat di tancapkan dan disusun sesuai dengan keinginan (Fadillah, 2017). Bermain lego, merupakan aktivitas yang menarik bagi anak, kepingannya bisa disusun model apa saja, berwarna-warni, ukuran yang berbeda dan berjumlah banyak. Untuk itu lego merupakan salah satu yang efektif dalam mengembangkan kemampuan motorik halus anak. Kemampuan motorik halus anak harus dilatih setiap hari dengan hal yang menyenangkan serta disukai anak-anak (Christiana \& Mahmudah, 2015). Kesulitan terjadi pada anak-anak yang kemampuan motoriknya masih kurang, sehingga permainan ini butuh di ulang kembali agar motorik halus setiap anak dapat berkembang. Melalui permainan edukatif lego, diharapkan kemampuan motorik halus anak dapat berkembang dan mendorong anak-anak untuk berpikir.

Permainan lego adu cepat berpengaruh secara signifikan terhadap kemampuan motorik halus anak (Christiana \& Mahmudah, 2015). Bermain konstruksi (lego) berpengaruh secara signifikan terhadap perkembangan motorik halus anak usia prasekolah, karena dengan bermain konstruksi (lego) akan menstimulasi gerakan jari jemari dan kecermatan antara mata dan tangan dalam penyusunan lego yang dilakukan oleh anak usia prasekolah (Devita, 2018). Terapi lego meningkatkan keterampilan motorik halus. Lego diberikan dalam tiga fase membuat anak lebih mampu mengambil potongan lego kecil dan menaruhnya bersama untuk membuat angka-angka tertentu. Pegangan potongan lego kecil memungkinkannya untuk mengontrol jarinya lebih bebas dan dengan demikian memegang krayon dan pensil lebih mudah (Pang, 2010). Peningkatan keterampilan motoric halus memungkinkannya untuk melakukan keterampilan dasar harian. Efek pemberian lego pada anak usia dini atau prasekolah mendorong aspek perkembangan anak (Cvijanović \& Mojić, 2018).

Penelitian yang telah dilakukan didapatkan hasil bahwa ada pengaruh alat permainan edukatif terhadap perkembangan motorik halus anak usia prasekolah. Hasil 
menunjukkan bahwa terdapat peningkatan perkembangan setelah dilakukan tindakan pemberian alat permainan edukatif.

Dilansir dari penelitian sebelumnya menjelaskan bahwa mainan yang ditujukan untuk perkembangan motorik anak mempunyai efek untuk meningkatkan perkembangan otot halus dan otot besar bersama dengan koordinasi mata dan tangan. Permainan adalah stimulasi yang sangat tepat bagi anak. Aspek perkembangan anak dapat ditumbuhkan secara optimal dan maksimal melalui kegiatan bermain (Aral et al., 2012). Bermain pada usia prasekolah telah terbukti mampu meningkatkan perkembangan mental, kecerdasan, daya pikir anak terangsang untuk mendayagunakan aspek emosional, sosial, serta fisiknya (Adriana, 2013).

Peneliti melakukan modifikasi sebagai standar dalam penelitian ini yaitu dengan memberikan APE lego pada anak usia prasekolah di setiap hari, dalam waktu 15 menit selama 2 minggu. Pemberian APE lego juga diberikan sesuai dengan usia anak dan kegiatan tersebut hanya dilakukan di sekolah selama dalam proses penelitian. Saat anak menggunakan APE lego secara tidak langsung anak akan diminta memecahkan sebuah masalah. Masalahnya adalah menggabungkan potongan-potongan. Otak anak akan dilatih untuk berpikir kreatif dengan menyusun kepingan lego. Ketika tangan memasang potongan lego, keterampilan motorik halus anak akan semakin terasah. Motorik halus adalah koordinasi antara otot-otot kecil. Semakin terampil anak memasang potongan lego, keterampilan anak akan semakin baik. Berulang kali anak mencoba memasang dan menggabungkan potongan lego, mambantu anak membuat kesimpulan sebuah masalah.

Hal ini sejalan dengan penelitian stimulasi dan intervensi sejak dini untuk meningkatkan kemampuan kecerdasan motorik sesuai dengan kelebihan dan kekurangannya. Kekurangan motorik halus anak bila terdeteksi sejak dini dapat dilakukan stimulasi dan latihan lebih rutin sejak kecil akan menghasilkan prestasi besar sesuai dengan kelebihan tingkat motoriknya (Livana et al., 2018). Hasil penelitian pada aspek perkembangan anak prasekolah sebelum diberikan alat permainan edukatif didapatkan kriteria meragukan sangatlah banyak sehingga diperlukan intervensi dengan menggunakan alat permainan edukatif. Aspek perkembangan pada anak sesudah diberikan alat permainan edukatif mengalami peningkatan perkembangan pada kriteria normal yang menunjukkan bahwa hasil tersebut sudah baik (Sain et al., 2013).

Penelitian ini sejalan dengan buku pedoman stimulasi dan deteksi tumbuh kembang anak (Kemenkes, 2012) dan manfaat intervensi dini 15-30 menit, sehari 3 kali, selama 2 minggu pada anak usia 6-12 bulan dengan penyimpangan perkembangan. Durasi intervensi ini cukup efektif untuk mengatasi keterlambatan (Susanty et al., 2014). Pemberian intervensi permainan edukatif selama 45 menit selama 2 minggu berpengaruh terhadap perkembangan anak usia prasekolah (Setyaningsih \& Wahyuni, 2018). Hasil penelitian lain tentang penggunaan permainan edukatif yang diberikan pada area perkembangan anak prasekolah selama 2 hari dalam seminggu dan setiap sesi sehari diberikan sekitar 60 menit dan 45 menit untuk jangka waktu selama lima minggu, ditemukan perbedaan yang antara anak kelompok kontrol dan eksperimen pada skor pra dan post test subskala The Brigance Early Development Inventory II signifikan $(\mathrm{p}<0.05)$ (Aral et al., 2012).

Perkembangan fisik dan usia anak, syaraf- syaraf yang berfungsi mengontrol gerakan motorik mengalami proses neurological maturation (kematangan neurologis). Kematangan secara neurologis merupakan hal yang penting dan berpengaruh pada kemampuan anak mengontrol gerakan motoriknya. Pada usia prasekolah dengan bertambahnya usia dan kematangan anak, sel-sel otak yang telah ada terus membesar, 
hubungan diantara sel-sel otak yang ada di dalam cortex tersebut menjadi sempurna dan membagi diri berdasarkan fungsi dan posisinya. Sel-sel otak yang berada di dalam cortex bertanggung jawab untuk melakukan tugas berpikir dan memecahkan masalah. Syaraf-syaraf yang berfungsi mengontrol motorik sudah mencapai neurological maturation dan menstimulasi berbagai kegiatan motorik yang dilakukan anak secara luas, diantaranya menggunakan jari-jari tangan untuk menyusun lego. Pada waktu yang bersamaan, persepsi visual motorik anak juga ikut berkembang dengan pesat (Papalia et al., 2010).

Anak yang mendapatkan stimulasi akan lebih cepat berkembang dari pada anak yang kurang atau bahkan tidak mendapat stimulasi. Stimulasi yang sangat tepat, menyenangkan dan bersifat mendidik bagi anak untuk meningkatkan perkembangan motorik halus dapat dilakukan dengan alat permainan edukatif. Pemberian alat permainan edukatif akan lebih efektif dan dapat mengoptimalkan perkembangan anak disesuaikan dengan usia dan tahap perkembangan anak.

\section{SIMPULAN DAN SARAN}

Penggunaan alat permainan edukatif mempunyai pengaruh yang efektif dalam meningkatkan perkembangan motorik halus anak usia prasekolah. Alat permainan edukatif dapat meningkatkan perkembangan motorik halus anak usia prasekolah. Diharapkan penggunaan alat permainan edukatif dapat dilakukan untuk menstimulasi seluruh aspek perkembangan disesuaikan dengan tahapan usia dan perkembangan anak.

\section{DAFTAR PUSTAKA}

Adriana, D. (2013). Tumbuh Kembang Dan Terapi Bermain Pada Anak, Edisi Revisi. Salemba Medika, Jakarta.

Aral, N., Gursoy, F., \& Yasar, M. C. (2012). An Investigation of the Effect of Puzzle Design on Children's Development Areas. Procedia-Social and Behavioral Sciences, 51, 228-233.

Christiana, M., \& Mahmudah, S. (2015). Pengaruh Permainan Lego Adu Cepat terhadap Perkembangan Motorik Halus Anak Kelompok A di Tk Aisyiyah 3 Surabaya. PAUD Teratai, 4(1).

Cvijanović, N., \& Mojić, D. (2018). LEGO Material in the Programme of Early Childhood and Preschool Education. Croatian Journal of Education: Hrvatski Časopis Za Odgoj i Obrazovanje, 20(Sp. Ed. 1), 25-45.

Devita, Y. (2018). Pengaruh Bermain Konstruksi (Lego) Terhadap Perkembangan Motorik Halus Anak Usia Prasekolah. Jurnal Keperawatan Priority, 1(2).

Fadillah, M. (2017). Bermain dan Permainan Anak Usia Dini. Jakarta: Kencana.

Fuadiyah, N. (2013). Upaya Meningkatkan Pengenalan Geometri dengan Permainan Puzzle Bervariasi pada Kelompok B TK Al-Hikmah Randudongkal-Pemalang Tahun Ajaran 2012/2013. IKIP PGRI Semarang.

Hildayani, R., \& Psi, S. (2014). Perkembangan Manusia. Psikologi Perkembangan Anak.

Ikram, T. P. F. (2018). Faktor risiko prenatal, natal dan postnatal anak usia 0-6 tahun dengan disabilitas di Poliklinik Rehabilitasi Medik RSUD Dr. Soetomo. Universitas Airlangga.

Kemenkes, R. I. (2012). Pedoman pelaksanaan stimulasi, deteksi dini dan intervensi dini tumbuh kembang anak di tingkat pelayanan kesehatan dasar. Jakarta: Dirjen Bina Kesmas. 
Livana, P. H., Armitasari, D., \& Susanti, Y. (2018). Pengaruh Stimulasi Motorik Halus Terhadap Tahap Perkembangan Psikososial Anak Usia Pra Sekolah. Jurnal Pendidikan Keperawatan Indonesia, 4(1), 30-41.

Mahardikha, M. A., \& Yuniarni, D. (n.d.). PERMAINAN EDUKATIF DENGAN MEDIA PUZZLE MENGEMBANGKAN KEMAMPUAN KOGNITIF ANAK USIA 4-5 TAHUN TK ISLAMIYAH.

Pang, Y. (2010). Lego games help young children with autism develop social skills. International Journal of Education, 2(2), 1.

Papalia, D. E., Old, S. W., \& Feldman, R. D. (2010). A child's world, infancy through adolescence (9th ed). (9 th). The McGraw-Hill Companies,Inc.

Riska, C. S., \& Satria, B. (2016). Alat Permainan Edukatif dengan Perkembangan Motorik Anak Usia Prasekolah di Kemukiman Lamlheu. Jurnal Ilmiah Mahasiswa Fakultas Keperawatan, 1(1).

Sain, S. N. H., Ismanto, A. Y., \& Babakal, A. (2013). Pengaruh Alat Permainan Edukatif Terhadap Aspek Perkembangan Pada Anak Pra Sekolah Di Wilayah Puskesmas Ondong Kabupaten Kepulauan Siau Tagulandang Biaro. E-NERS, 1(1).

Setyaningsih, T. S. A., \& Wahyuni, H. (2018). Stimulasi Permainan Puzzle Berpengaruh terhadap Perkembangan Sosial dan Kemandirian Anak Usia Prasekolah. Jurnal Keperawatan Silampari, 1(2), 62-77.

Soetjiningsih, R. G. (2013). Buku Tumbuh Kembang Anak Edisi 2. Jakarta: Penerbit Buku Kedokteran EGC.

Susanto, A. (2016). Perkembangan anak usia dini : pengantar dalam berbagai aspeknya. In International Journal of Adolescence and Youth (Vol. 3, Issue 1). Kencana. https://doi.org/10.1080/02673843.2013.847850

Susanty, A., Fadlyana, E., \& Nataprawira, H. M. (2014). Manfaat intervensi dini anak usia 6-12 bulan dengan kecurigaan penyimpangan perkembangan. Majalah Kedokteran Bandung, 46(2), 63-67.

Wahyuni, C. (2018). Hubungan Pengetahuan, Sikap dan Perilaku tentang Stimulasi Dini dengan Perkembangan Motorik Halus Anak Usia 1-3 Tahun di Kelurahan Balowerti Kota Kediri. Journal for Quality in Women's Health, 1(2), 35-42.

Winarti, E. (2016). Pengaruh Permainan Lego Konstruktif Terhadap Perkembangan Motorik Halus Pada Anak Prasekolah Di TK-IT At Taqwa II. Java Health Jounal, 3(1), 7 .

Wong, D. L. (2009). Buku ajar keperawatan pediatrik vol 1 wong. 